\title{
Broadening the scope: The Urgenda case, the Oslo Principles and the role of national courts in advancing environmental protection concerning climate change
}

\author{
Pau DE VILCHEZ MORAGUES ${ }^{*}$
}

\begin{abstract}
In the light of the insufficient and inadequate action by public authorities on environmental matters, courts have started playing a fundamental role in the protection of nature and the human rights thereto related. Concerning climate change, national litigation is undoubtedly becoming a crucial element of the fight against global warming and its predictable catastrophic consequences. Domestic courts, through the identification and operation of different legal tools and principles, both national and international, might be providing an enhanced level of protection of fundamental rights, like the right to life, to health or even to property, currently threatened by the disruptive consequences of climate change. Simultaneously, several academic initiatives are elaborating concurring proposals based on very similar legal grounds, thus reinforcing the courts' standpoint. However, the potential heterogeneity of judicial decisions, even more among different national jurisdictions, should be considered a sufficient reason to keep on pushing for sufficiently clear and ambitious international norms concerning climate change.
\end{abstract}

Keywords: climate change - litigation - human rights - tort law - precautionary principle.

\section{(A) INTRODUCTION}

It is undeniable that one of the main victims of the industrial revolution and the carbon economy that has developed since the igth century is the environment. The slow and unsteady realization by national authorities and the international community of the inseparable fate of nature and humankind has brought about some interesting international declarations and covenants especially since the 1970's (e.g. the Stockholm Declaration on Human Environment of 1972 or the Rio Declaration of 1992). At about the same time, several countries started including in their national constitutions the protection and the enjoyment of a healthy environment as one of the distinctive rights of their citizens.2

However, that prise de conscience has so far been unable to provide a comprehensive and effective framework for the protection of the environment in its many manifestations (biodiversity, the climate system, clean air and water, or a stable geology, among others), very often with serious consequences upon the human communities living in, and depending on that environment. Indeed, it has proved

* Assistant Research Lecturer of International Law and PhD candidate, Faculty of Law, University of the Balearic Islands (UIB), pau.devilchez@uib.eu. This article is a revised version of a study presented at the IV UCL-KCL Postgraduate Environmental Law Symposium, held in February 2016 at King's College London. This article was undertaken within the framework of the research project DER2015-65486-R, funded by the Ministerio Espanol de Economia y Competitividad.

I Declaration of the United Nations Conference on the Human Environment, Stockholm, I6 June 1972, UN Doc. A/CONF.48/I4/Rev.I ('Stockholm Declaration'); Rio Declaration on Environment and Development, I3 June 1992, UN Doc. A/CONF.I5I/26.Rev.I ('Rio Declaration').

2 See, for example, Article 45 of the Spanish Constitution (1978), or Article 66 of the Portuguese Constitution (1976). 
very difficult to translate, at the international level, the many principles established in those international instruments into clearly defined binding obligations for States or even the private sector. In recent years, climate change has become one of the greatest environmental problems of our time, if not the greatest. ${ }^{3}$ It is a human-driven environmental threat of such a magnitude that its impacts on both nature and human rights are critical at a multidimensional level. There are no longer any doubts that climate change will have a severe impact on the very fundamental rights of humankind, such as the right to life, to clean and safe water or the right to food, although it is not yet known to what extent, where and when this will happen.

\section{(B) CLIMATE CHANGE AND THE COURTS}

In the face of such a danger, NGOs and concerned individuals but also, increasingly, scholars and lawyers, have started considering litigation as the most promising avenue to obtain the decisive action needed to mitigate climate change at a level compatible with human dignity. Consequently, several lawsuits have been initiated in recent years against states' climate policies, mostly at the national level. ${ }^{4}$

Countries like the Netherlands, the US, Belgium, Pakistan, New Zealand, Sweden or Norway have recently witnessed lawsuits filed by their citizens against their governments' policies, or lack of them, concerning climate change.

In all of these cases, the plaintiffs (either citizens or associations) judicially require the State (or a state agency) to conduct a much stricter climate change policy, especially concerning the level of greenhouse gas (GHG) emissions. And the more striking feature about those lawsuits is that some of them have actually succeeded, like in the Netherlands, Pakistan or the US. We will analyse here some of those cases in order to identify their main legal aspects, pointing out similarities and differences among them.

\footnotetext{
3 "[...] the greatest challenge and threat for mankind in living memory." Expert Group on Global Climate Obligations, Oslo Principles on Global Climate Obligations (Eleven International Publishing, 20I5), at I3.

4 It is true that in recent times some interesting climate cases against corporations have started to develop, thus providing another angle for addressing climate change responsibility and raising very interesting questions of liability, causality and foreign courts' jurisdiction. The lawsuit filed in November 2015 by a Peruvian farmer against German utility RWE at the Regional Court in Essen, (Germany), asking for a financial contribution in order to adapt to climate change caused, partly, by the German company, is one of the most relevant examples of that line of cases (Saul Luciano Lliuya $v$. RWE). An interesting overview of the different lawsuits against private corporations can be found at $\mathrm{K}$. Boom et al., Climate Iustice: The international momentum towards climate litigation (Climate Justice Program and Heinrich Böll Stiftung, 2016). However, in this paper we will be analysing only climate change domestic litigation against states, as it might provide a firmer ground upon which to identify obligations for the current main subjects of international law. From an international perspective, the Inuit petition to the Inter-American Commission on Human Rights in 2005 was certainly an interesting attempt to request the intervention of supra-national organizations, but the Commission rejected the petition without even taking it into consideration, allegedly because it didn't provide enough information to examine the case.
} 
(I) Current and Recent Climate Change National Litigation Cases

In order to have a global and more accurate appraisal of the situation, we will examine in this study some of the most recent and relevant climate change cases from three different continents: Europe, America and Asia.

First, the Urgenda case, ${ }^{5}$ where a Dutch court ordered the State of the Netherlands to increase its GHG reduction targets for 2020 following a claim by the Urgenda Foundation, together with 886 Dutch citizens. The Dutch Government announced on I September 2015 its intention to appeal the decision and the decision on appeal is still pending. ${ }^{6}$

Secondly, the so-called Washington Kids Climate Case in the US,7 initiated by 8 minors asking the court to overrule the Washington Department of Ecology's denial of their petition for a more ambitious reduction of GHG emissions consistent with current scientific assessments. A Directive of the State's Governor during the proceedings, requiring the Department to initiate a rulemaking on the matter, prompted the court to dismiss the claimants' petition, but not before recognizing the validity of their claim. ${ }^{8}$

Thirdly, in Belgium, the not-for-profit organization Klimaatzaak initiated in April 2015 a very similar case to Urgenda, asking the Belgian federal and regional authorities to further reduce the GHG emissions of Belgium in the 2020 horizon?

Fourthly, in August 2015, Ashgar Leghari, a farmer from Pakistan, filed a Public Interest Litigation against the Federal government of Pakistan and the Provincial government of Punjab, urging them to develop the National Climate Change Policy of Pakistan, especially regarding adaptation issues. The High Court of Lahore granted the plaintiff's request and ordered the authorities to implement the abovementioned policy. ${ }^{\text {IO }}$

Fifthly, also in August 20I5, 2I young plaintiffs, together with non-profit organization Earth Guardians and Dr. James Hansen acting as a guardian for future generations, filed a lawsuit against the USA, the President of the USA and several other officers and Federal agencies, seeking relief from

5 The Urgenda Foundation v. The Netberlands, Judgment, 24 June 2015, ECLI:NL:RBDHA:2015:7196, Rechtbank Den Haag (The Hague District Court). As one of the most detailed decisions in the matter to date, we will often rely on it to illustrate our analysis.

6 Several studies on the case and its implications have been published since then. See, among others, R. Cox, 'A Climate Change Litigation Precedent: Urgenda Foundation v. The State Of The Netherlands', 79 CIGI Papers (2015); K. J. de Graaf and J. H. Jans, 'The Urgenda Decision: Netherlands Liable for Role in Causing Dangerous Global Climate Change', 27 Journal of Environmental Law (2015) 517-527 [doi: 10.1093/jel/eqv030]; T. Parejo, 'La victoria de Urgenda: El inicio de la lucha judicial frente al cambio climático', I77 Revista Española de Derecho Administrativo (2016) 259 - 279.

7 Zoe and Stella Foster et al. v. Wasbington Department of Ecology, Order No. 14-2-25295-I SEA, I9 November 2015, Superior Court of the State of Washington for King County.

8 In a recent development, on 28 April 2016, after the Department of Ecology had withdrawn the initial draft rule on February 2016 the judge ordered the Department to promulgate an emissions reduction rule by the end of 2016 and make recommendations to the state legislature on science-based greenhouse gas reductions in the 2017 legislative session. Zoe and Stella Foster et al. v. Wasbington Department of Ecology, Order on petitioners' motion for relief under CR 6o(b) No. I4-225295-I, I6 May 2016, Superior Court of the State of Washington for King County.

9 Asbl Klimaatzaak v. the State of Belgium, the Région Wallone, the Région Flamande, and the Région de BruxellesCapitale, summons issued on 27 April 2015, Tribunal de Première Instance de Bruxelles.

ro Ashgar Leghari v. Federation of Pakistan, Order, 4 September 2015 W.P. No. 2550I/2015, Lahore High Court Green Bench. 
the Administration's lack of action against, or even its actions fostering climate change. On April the $8^{\text {th }}$ 2016, the District Court of Oregon rejected the motions of dismiss presented by the US Federal Government and three trade associations representing many of the biggest fossil fuel companies around the globe."I

Finally, in France, a young association called Notre Affaire à Tous presented a preliminary request ("action indemnitaire préalable") to the French authorities on December the $4^{\text {th }} 2015$, asking for a $25 \%$ to $40 \%$ reduction of France's GHG emissions in 2020 compared to 1990 levels..$^{12}$ This case is very similar to those in The Netherlands and Belgium and it has not yet reached the courts. ${ }^{13}$

\section{(2) Common core litigation elements}

Most of the above-mentioned lawsuits share a common core of legal grounds, built upon a solid scientific basis as well as on both international and national law. We will, hence, analyse here the similarities and parallelisms of the different cases in those matters, pointing out the differences among them whenever necessary.

\section{(a) Scientific evidence}

A strong scientific basis is a common feature of all the aforementioned cases. Claimants and courts alike refer exhaustively to research and findings by national and international scientific institutions.

At the national level, in France, the non-profit organization Notre affaire à tous recalls findings by the Observatoire Nationale sur les Effets du Changement Climatique (ONERC). ${ }^{14}$ In Belgium, Klimaatzaak points to research conducted jointly by the Universite Catholique de Louvain and Greenpeace in 2004, as well as a 2010 report by the Institut Scientifique de Santé Publique. .5 $^{\text {The }}$ Court in the Urgenda case refers to The Netherlands Environmental Assessment Agency (PBL) and The Royal Netherlands Meteorological Institute (KNMI). ${ }^{16}$ And in the USA, claimants in Kelsey

\footnotetext{
II Kelsey Juliana et al. v. The United States of America et al. Case number 6:15-cv-01517-TC, Order and Findings and Recommendation, 8 April 2016, United States District Court, District of Oregon - Eugene Division.

I2 Although the preliminary request is not available on line, some information can be found at the association's website. The association can be asked by e-mail to provide a copy of the preliminary request.

I3 There are currently a few other cases, at different procedural stages, which will not be analysed in this article, either because of their recent filing or because of the absence of available information. On April 20r6, a second climate case was filed in Pakistan, this time by a nine-year-old girl (Rabab Ali v. Federation of Pakistan and another, Supreme Court of Pakistan). On recent months, two new climate lawsuits have been introduced in Europe: two NGOs, PUSH Sweden and Fältbiologerna filed the first one on I5 September 2016, against the Swedish government, following the government's decision to authorize the selling of its coal assets in Germany to a company from the Czech Republic. The second one was filed in Norway on I8 October 2016, by Greenpeace Norway and Nature and Youth, opposing the government's new oil drilling permits in the Artic. The writ of summons is available at Greenpeace's webpage. On the other hand, an application for judicial review against the Minister for Climate Change Issues of New Zealand was registered in November 2015 at the High Court of New Zealand by Sarah Thomson, a university student, for failing to set an appropriate GHG reduction target as well as a sufficient INDC (Intended Nationally Determined Contribution) compatible with avoiding dangerous human interference with the climate system (Sarab Lorraine Thomson v. The Minister for Climate Change Issues, Statement of Claim dated ro November 2015, High Court of New Zealand, Wellington Registry.).

${ }^{4}$ Notre Affaire à Tous, supra n. I2, at I.

is Klimaatzaak v. Belgium, supra n. 9, at 9-I2.

I6 Urgenda v. The Netherlands, supra n. 5, at $\$ 2.22$ to $\$ 2.24$.
} 
Juliana refer to several reports, among which an Environmental Protection Agency (EPA) report of 1990 and the National Climate Assessment of 2014. ${ }^{17}$

At the international level, the Intergovernmental Panel on Climate Change (IPCC) is the most cited source of scientific expertise on climate change. The IPCC is not only a respected source of evidence, providing both up to date and, more importantly, almost undisputed scientific evidence of the current trends in climate change research. In fact, the way the IPCC works and produces its reports, similarly to an adversarial procedure, with several levels of checks and balances, both from a scientific and a political point of view, from national as well as international institutions, constitutes a fundamental quality that allows some claimants to confer a special legal status to those reports. ${ }^{{ }^{8}}$

What the prevailing scientific evidence says is widely known: at the current pace, without drastically reducing our greenhouse gas emissions, we are heading towards a much warmer world, well above the $2^{\circ} \mathrm{C}$ target set forth at the Cancun Agreement in 2010, ${ }^{19}$ thus causing unprecedented meteorological havoc, droughts, floods, extreme storms, sea-level rise, living species' extinction and many other phenomena that will undoubtedly have an enormous negative impact upon human wellbeing.

The relevant part of the scientific research cited in those judicial procedures relates to:

- The temperature threshold below which it is most probable to avoid climate disruption (Between $2^{\circ} \mathrm{C}$ and $\left.\mathrm{I} .5^{\circ} \mathrm{C}\right) ;^{20}$

- The level of GHG presence in the atmosphere needed to stay below that threshold (Between 430 ppm and $450 \mathrm{ppm}$, by the end of the century), ${ }^{2 \mathrm{I}}$ and

- The pace and intensity of the reductions in GHG emissions needed to reach this goal, as well as the different possible scenarios depending on the pace and intensity of those reductions (Between $25 \%$ and $40 \%$ in 2020 , and between $80 \%$ to $95 \%$ in 2050$){ }^{22}$

${ }_{17}$ Kelsey Juliana $v$. The United States of America, First amended complaint for declaratory and injunctive relief. Case No.: 6:15-cv-o1517-TC, io Sep. 2015, at 58 and 72.

${ }_{18}$ "La principale preuve scientifique du changement climatique et de ses conséquences se retrouve dans les rapports du GIEC. Ces rapports ont une valeur juridique toute particulière. (...) Les points de vue scientifiques sont donc soumis à un processus contradictoire qui se déroule à trois niveaux, raison pour laquelle les constats du GIEC bénéficient d'un statut particulier", Klimaatzaak summons, supra n. 9, at 8-9. The argument is further developed by Roger Cox, lawyer of the claimants in both the Urgenda and Klimaatzaak cases, in R. Cox, Revolution Justified (Planet Prosperity Foundation, e-book, 20I2), at 3II-316. Similarly, The International Bar Association published a report in 20I4, where it praised the "thorough", "continuous" and "collaborative" work of the IPCC. Climate Change and Human Rights Task Force, Acbieving Justice and Human Rights in an Era of Climate Disruption (International Bar Association, 2014), at 38. In Sarah Lorraine Thomson v. The Minister for Climate Change Issues, the scientific argumentation of the case is essentially also based on the IPCC reports, while, interestingly, also relying on N. Stern et al., Review Report on the Economics of Climate Change (Cambridge University Press, 2016) for the economic implications of taking prompt action to cut GHG emissions or delaying it. Supra $\mathrm{n}$. I3, at $\$ \$ 15-40$ and $\$ \$ 49-52$.

19 The Paris Agreement, which sets forth an objective of "well below $2^{\circ} \mathrm{C}$ above pre-industrial levels and pursuing efforts to limit the temperature increase to $1.5^{\circ} \mathrm{C}$ above pre-industrial levels", was adopted several months after most of those lawsuits were filed or analysed by the courts, on I2 December 2015.

20 Urgenda v. The Netherlands, supra n. 5, at \$2.12 and \$4.I4, citing IPCC assessment reports AR4/2007 and AR5/2013.

2i Ibid., at $\$ 2.19$ and $\$ 4.20$, referring to the same IPCC reports.

22 Ibid., at $\$ 4.23$ to $\$ 4.29$. 
In Urgenda, for instance, after assessing all these facts and estimates, The Hague District Court acknowledged the relevance of those findings and ruled against the State, deciding that the Netherlands should define and enact a climate change policy that allowed for it to reach, at least, the lower target defined as safer by the IPCC (i.e. $25 \%$ in 2020).23 We will see below what was the legal reasoning for such an unprecedented decision.

\section{(b) International obligations}

In addition to scientific evidence, courts and claimants also refer extensively to international law, fundamentally through three different sources: International environmental law, human rights law and, in EU countries, European Union law. ${ }^{24}$ We will examine here how those three sources add to the referred scientific basis to build up relevant obligations for the State concerning climate change, which will be completed by the application of national law, as we will have the opportunity to consider on the following section.

\section{(i) International environmental law}

From a conventional perspective, the United Nations Framework Convention on Climate Change (UNFCCC) ${ }^{25}$ and the Kyoto Protoco ${ }^{26}$ are commonly cited, ${ }^{27}$ while other agreements or decisions relating to the UN's Climate Change framework, like the Cancun agreements ${ }^{28}$ or the Doha amendment ${ }^{29}$ are less frequently mentioned. The relevance of those texts derives essentially from the principles and goals they all set, rather than from the limited obligations arising from some of them..$^{\circ}$ Several principles are derived from the abovementioned conventional sources, but also from customary norms and even international judicial bodies' decisions, both from regional and universal nature, like the European Court of Human Rights (ECtHR) or the International Court of Justice (ICJ), such as the no-harm principle, the prevention principle, the precautionary principle, the equity principle and the principle of sustainable development. It is not the object of this paper to retrace the evolution of those principles in the international sphere, neither from the perspective of treaties nor from the practice of States or International Organizations, as more distinguished scholars have already

Ibid., at $\$ 4.86$

24 International environmental law is the source of many of the principles and obligations called forth by claimants and courts in Europe, while courts and claimants in the US and Pakistan refer pre-eminently to domestic law.

25 United Nations Framework Convention on Climate Change, 9 May 1992, I77I UNTS I07 ('UNFCCC').

${ }_{26}$ Protocol to the United Nations Framework Convention on Climate Change, Kyoto, II December 1997, 2303 UNTS 148.

27 Kelsey Juliana v. The United States of America, supra n. I7, at 59-60. Urgenda v. The Netherlands, supra n. 5, at \$\$2.35 to 2.52. Klimaatzaak v. Belgium, supra n. 9, at $\mathrm{I} 2-\mathrm{I} 3$.

28 The Cancun Agreements: Outcome of the work of the Ad Hoc Working Group on Long-term Cooperative Action under the Convention, Decision I/CP.I6, I5 March 20II, doc. FCCC/CP/20Io/7/Add.I; The Cancun Agreements: Outcome of the work of the Ad Hoc Working Group on Further Commitments for Annex I Parties under the Kyoto Protocol at its fifteenth session, Decision I/CMP.6, is March 20II, doc. FCCC/KP/CMP/2010/ı2/Add.I.

29 Doha Amendment to the Kyoto Protocol, Doha, Decision I/CMP.8, 8 December 2012 , doc. $\mathrm{FCCC} / \mathrm{KP} / \mathrm{CMP} / 2 \mathrm{OI} / \mathrm{I}_{3} /$ Add.I.

30 Although the Kyoto Protocol did actually establish very precise commitments, the reduced number of member parties having binding GHG reduction targets inevitably diluted its reach. 


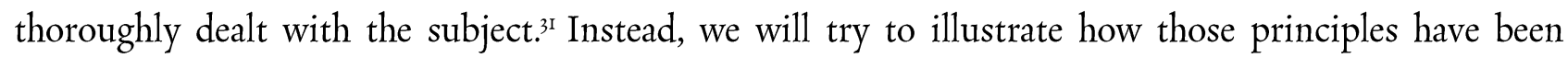
incorporated in the abovementioned lawsuits in order to better identify States' obligations concerning climate change.

First of all, the no-harm and the prevention principles, which are often used in an equivalent sense in those cases. Originally formulated at the Stockholm Declaration on 1972, the Prevention Principle, which affirms the sovereign right of States to use its natural resources while at the same time establishing their responsibility to avoid damaging the environment of areas beyond its jurisdiction, was developed as an evolution from the no-harm principle, which was essentially based upon the traditional approach to State responsibility and neighbouring relations. ${ }^{32}$ Twenty years later, the prevention principle was incorporated to the Rio Declaration as Principle 2.

Both concepts are used in a very similar way in the lawsuits examined in this article: while the court in Urgenda refers mainly to the no-harm principle, affirming that it requires States to ensure that activities within their jurisdiction or control do not cause damage to the environment of other States or of areas beyond the limits of their national jurisdiction, ${ }^{33}$ claimants in Klimaatzaak stress the relevance of the prevention principle, recalling that it tries to avoid situations of harm and risk that are known and where the causality effect has been established ${ }^{34}$

Additionally, in Klimaatzaak, plaintiffs recall the ECtHR jurisprudence in Boudayeva v. Russia and Öneryildiz v. Turkey, as well as the ICJ decision on the Pulp Mills case, together with recital 8 of the UNFCCC and article 191.2 of the Treaty on the Functioning of the European Union (TFUE) 35 in order to properly define the extent of the prevention principle . $^{36}$

The precautionary principle is, in turn, one of the three main pillars of the legal reasoning behind most of the lawsuits, together with human rights law and tort law, which will be analysed in the corresponding section of this article. A definition of the precautionary principle is provided by principle Is of the Rio Declaration:

"In order to protect the environment, the precautionary approach shall be widely applied by States according to their capabilities. Where there are threats of serious or irreversible damage, lack of full scientific certainty shall not be used as a reason for postponing cost-effective measures to prevent environmental degradation."37

3I See, among others, N. De Sadeleer, Essai sur la genèse et la portée juridique de quelques principes en droit de l'environnement (Bruylant, Bruxelles, 1999); A. Kiss and D. Shelton, International Environmental Law (3 ${ }^{\text {rd }}$ ed., Transnational Publishers, New York, 2004), at II3; P.-M. Dupuy and J.E. Viñuales, International Environmental Law (Cambridge University Press, 2015), at 5I-90.

32 For an account of the significance, evolution and scope of the prevention principle see L.-A. Duvic Paoli and J. E. Viñuales, 'Principle 2: Prevention', in J.E. Viñuales (ed.), The Rio declaration on Environment and Development. A commentary (Oxford University Press, 2015), at 107-138.

33 See Urgenda v. The Netherlands, supra n. 5, at \$4.39. The Hague District Court also refers to the prevention principle, but only once and in relation to EU law, at $\$ \$ 4.60-4.6 \mathrm{I}$.

34 See Klimaatzaak v. Belgium, supra n. 9, at $\$ 70$.

35 Consolidated Version of the Treaty on the Functioning of the European Union, 2008 O.J. C II5/47.

36 Boudaïeva et autres c. Russie, ECtHR, 20 Mar 2008, appl. no. 15339/02; Öneryıldız v. Turkey, ECtHR, 30 Dec 2004, appl. no. 48939/99 Judgment 30.II.2004 [GC]; Pulp Mills on the River Uruguay (Argentina v. Uruguay), Judgment, ICJ Reports (20IO). p. I4.

37 Rio Declaration, supra n. I. 
When analysing the above-mentioned cases, the power of the precautionary principle seems to lay in its capacity to deal with the uncertainties of climate change and to link them, through the appraisal of the possible impairments deriving from it, to the necessity of taking action to prevent a potential harm.

However, it is worth noting that the uncertainty is not related to whether climate change will or will not occur. The IPCC reports and the political authorities of more than roo countries around the world affirm what is already scientifically virtually undisputed: climate change is already happening. ${ }^{38}$ And courts are also acknowledging that fact.39

Indeed, what now needs to be ascertained is when, where and how will the disastrous manifestations of climate change reveal themselves, and when shall actions directed to avoid climate change start, with what intensity and at what pace..$^{4}$

Following the legal reasoning in those cases, the application of the precautionary principle to climate change would require governments to put most of the efforts on mitigation strategies, as the consequences of a global average rise of temperatures above $2^{\circ} \mathrm{C}$ would cause greater damage and at a much higher cost than what could be prevented through adaptation. It also obliges States to start as soon as possible those mitigation actions, with an intensity and at a pace consistent with the requirements set by current confirmed science. For, on the one hand, the later we start mitigating climate change, the harder and costlier it would be, and on the other hand, if GHG emissions are not reduced at the required levels (say, for example, $25 \%$ to $40 \%$ by 2020 ), the probability to stay below the $2^{\circ} \mathrm{C}$ threshold will be much lower. $4^{\mathrm{I}}$

The precautionary principle thus works together with the latest available scientific knowledge in order to define what action would be required to avert dangerous climate change. Not only claimants in the abovementioned proceedings have maintained this, but also several courts have come to confirm it, like the High Court of Lahore in Pakistan ${ }^{42}$ or The Hague District Court, which refers to the precautionary principle to analyse whether there is a breach in the duty of care of the sate towards its citizens and Urgenda itself.43

Third, the equity principle is also widely relied upon both by claimants and courts alike. Taken from its intergenerational dimension, equity obliges us to take into consideration the well-being not only of present generations but also of generations to come, as has been acknowledged by courts in

\footnotetext{
38 "Human influence on the climate system is clear, and recent anthropogenic emissions of green-house gases are the highest in history. Recent climate changes have had widespread impacts on human and natural systems. (...) Warming of the climate system is unequivocal, and since the I950s, many of the observed changes are unprecedented over decades to millennia. The atmosphere and ocean have warmed, the amounts of snow and ice have diminished, and sea level has risen." IPCC, 20I4: Climate Change 20I4: Synthesis Report. Contribution of Working Groups I, II and III to the Fifth Assessment Report of the Intergovernmental Panel on Climate Change [Core Writing Team, R.K. Pachauri and L.A. Meyer (eds.)]. IPCC, Geneva, Switzerland, at 2.

From a legal perspective, see, for example, recital 5 of the Adoption of the Paris Agreement.

39 Urgenda $v$. The Netherlands, supra n. 5 , at $\$ 4.18$.

40 Ibid., at \$4.19. From a different legal culture, see, for example, Ashgar Leghari v. Federation of Pakistan, Order, I4 September 2015 W.P. No. 2550I/2015, Lahore High Court Green Bench, specifically ground 8 of the decision.

${ }_{41} \quad$ Urgenda v. The Netherlands, supra n. 5, at $\$ 94.7 \mathrm{I}, 4.73$ and 4.85 .

${ }^{42}$ Ashgar Leghari v. Federation of Pakistan, supra n. IO, grounds 7 and 8.

43 Urgenda v. The Netherlands, supra n. 5, at $\$ 4.63$.
} 
the Netherlands ${ }^{44}$, Pakistan ${ }^{45}$ and the US. The Kings County Superior Court, for example, heavily insisted in its order in the fact that "[the] very survival [of the claimants] depends upon the will of their elders to act now". ${ }^{46}$

Similarly, from an economic and historical perspective, equity, or fairness, usually referred to as "common but differentiated responsibilities" in international environmental instruments, 47 is used by claimants and courts to justify the need of a more ambitious climate policy by wealthier countries that have derived their privileged present situation from the intense use of fossil fuels. Thus, GHG reduction targets in countries like the Netherlands or Belgium, even though they are already stricter than in many other countries, should be even more ambitious because of both their capacity and historical responsibility. The Hague District Court phrases it very clearly in its judgement:

"The principle of fairness also expresses that industrialised countries have to take the lead in combating climate change and its negative impact. The justification for this, and this is also noted in literature, lies first and foremost in the fact that from a historical perspective the current industrialised countries are the main causers of the current high greenhouse gas concentration in the atmosphere and that these countries also benefited from the use of fossil fuels, in the form of economic growth and prosperity. Their prosperity also means that these countries have the most means available to take measures to combat climate change." ${ }^{48}$

The above-mentioned reasoning by the court in Urgenda is capital to refute a de minimus defence by developed countries, which tend to reject any obligation to take more ambitious measures against climate change arguing that their domestic contribution to global emissions of GHG is marginal. ${ }^{49}$

Fourth and last, the principle of sustainable development, coined in the Brundtland report and which also appears in the UNFCCC as well as in the Kyoto Protocol, establishes the need to balance economic development and environmental protection with a long time perspective (without compromising the ability of future generations to find the means for their well-being), ${ }^{5 \circ}$ and although courts do not primarily rely on this principle alone in their rulings, it provides a firmer ground for their decisions, strengthening the application of the other principles mentioned above.5

44 Ibid., at $\$ \$ 4.57$ and 4.76 .

45 Ashgar Leghari v. Federation of Pakistan, supra n. Io, ground 7.

46 Zoe and Stella Foster et al. v. Washington Department of Ecology, supra n. 7, at 5 .

47 Originally sketched at the Stockholm Declaration and chiselled through the practice surrounding the Ozone regime, the principle of common but differentiated responsibilities was enshrined as principle 7 of the Rio Declaration. P. Cullet, 'Principle 7: Common but Differentiated Responsibilities', in J.E. Viñuales (ed.), The Rio declaration on Environment and Development (...), supra n. 32, at 229-244.

${ }_{48}$ Urgenda $v$. The Netherlands, supra n. 5 , at $\$ 4.57$.

49 D. Estrin, 'Limiting Dangerous Climate Change. The critical role of citizen suits and domestic courts - despite the Paris Agreement', IOI CIGI Papers (20I6), at I3. Professor Estrin points out to a similar position taken by Common Law courts: "This reasoning is similar to a strong common law line of authority regarding tort nuisance claims, which holds that 'it is no defence to a nuisance claim that others are also contributing to the nuisance.' In the United States, even the US Supreme Court in its Massachusetts v EPA decision rejected this defence, finding that '[a] reduction in domestic emissions would slow the pace of global emissions increases no matter what happens elsewhere." Massacbussets et al. v. Environmental Protection Agency et al., US Supreme Court, No. 05-II20.

so "Sustainable development is development that meets the needs of the present without compromising the ability of future generations to meet their own needs.", United Nations, Report of the World Commission on Environment and Development: Our Common Future (Brundtland Report) (1987), Chapter 2 @I.

${ }_{51}$ Ashgar Leghari v. Federation of Pakistan, supra n. IO, ground 7, and Urgenda v. The Netherlands, supra n. 5, at $\$ 4.8$. 


\section{(ii) Human rights law}

Human rights law is the second main source of obligations, from an international law perspective, arising from those lawsuits. Furthermore, together with the precautionary principle, discussed above, and tort law, which will be considered below, human rights law constitutes one of the three fundamental bases of climate change domestic litigation so far.

Human rights currently represent the most advanced legal framework protecting human dignity. Through a myriad of instruments and conventions, at both the international and regional level, there's a wide understanding of what constitutes the minimum rights human beings should be entitled to. Over the last 30 years, there has been a continuously increasing understanding of the sometimes complex interrelations between human rights and the environment, gathering recognition from international organizations and instruments, legal practitioners, courts, NGOs and scholars. ${ }^{52}$

However, although there have been some attempts at internationally establishing a human right to the environment (starting from the Special Rapporteur on Human Rights and the Environment of the UN Commission of Human Rights, Fatma Zohra Ksentini, 1994 Draft Principles on Human Rights and the Environment),, 3 only some regional instruments have so far recognized such a right, ${ }^{54}$ as well as an increasing number of national constitutions all around the globe. 55 In Europe, the absence of a clearly defined right to a healthy environment at the European Convention of Human Rights (ECHR) has not prevented the ECtHR from providing a gradually higher degree of environmental protection whenever a clear link has been established between an action harmful to the environment and the impairment of a conventional human right..$^{56}$

52 The subject has been and still is the object of vibrant research. See, among others, A. Boyle, 'Human Rights or Environmental Rights? A Reassessment', Vol XVIII, Fordham Environmental Law Review, 47I-5II. A short analysis of what the authors call "Human Rights Approaches" is provided by P-M. Dupuy, supra n. 3I, at 247. For an overview of the current research, see A. Grear and L. Kotzé, Research Handbook on Human Rights and the Environment (Edward Elgar Publishing, 2015). At the international level, one of the most recent decisions underlying the close connection between human rights and the environment was the appointment by the UN Human Rights Council, in 2012, of an Independent Expert on Human Rights and the Environment, with the mandate to study human rights obligations in relation to the enjoyment of a safe, clean, healthy and sustainable environment as well as to promote best practices on the subject. Independent Expert John Knox has set up a website where all the reports, research material and documents are publicly available: http://srenvironment.org/.

53 Even more than twenty years (and countless environmental crises) after it was first presented, the Draft Declaration is still innovative and, to some extent, challenging. Draft Principles on Human Rights and the Environment. Annex I to the Final report of the Special Rapporteur to the UN Commission on Human Rights, 1994.

54 In the Inter-American system, Article II.I of the San Salvador Protocol declares the right to a healthy environment. Organization of American States (OAS), Additional Protocol to the American Convention on Human Rights in the Area of Economic, Social and Cultural Rights ("Protocol of San Salvador"), I6 November 1999, A-52. In the African system, Article 24 of the African Charter on Human and Peoples' Rights recognizes that "All peoples shall have the right to a general satisfactory environment favorable to their development". Organization of African Unity (OAU), African Charter on Human and Peoples' Rights ("Banjul Charter"), 27 June 198I, CAB/LEG/67/3 rev. 5, 2I I.L.M. 58 (1982).

55 In Africa, for instance, such a right appears in the Constitution of Angola (Article 24) of 1992, and the Constitution of Mali (Article I5) of 1992. In America, similar provisions can be found in the Constitutions of Argentina (Article 4I) after the reform of 1994, and Colombia (Article 49) of 1991. In Europe, the Constitutions of Croatia (Article 69) of 200I, and of Finland (Article 20) of 1999 , among others, also recognize the right to a safe and healthy environment.

56 See, among others, Öneryildiz v. Turkey, supra n. 36 or López Ostra v. Spain, ECtHR, 9 Dec. 1994, appl. no. 16798/90, [1994] Series A, No. 303-C A. For an extensive critical review of the ECtHR jurisprudence regarding the environment and possible paths of evolution as compared to the Inter-american and African human rights' systems see R. Pavoni, Interesse 
In that context, in the light of the hesitant, insufficient and often inadequate action (not to mention the occasional obstruction) by public authorities on those matters, courts have increasingly started playing a fundamental role in the protection of nature and the human rights thereto related.57

Concerning climate change, the human rights perspective helps to identify what dimensions of human dignity are directly affected by it. The list of substantive rights potentially impaired by climate change is considerable: the right to life, the right to private and family life, the right to health, to water, to food and also the right to property. And, although we will not be dealing with that question in this paper, one cannot but recognize that even the right to self-determination of the peoples is already being affected by climate change ${ }^{58}$

All of the cases examined in this article refer to the violation of human rights derived from the impacts of climate change, thus reaffirming the link between fundamental human rights and the environment. The cases brought before national jurisdictions in Europe refer to the ECHR and to the ECtHR's jurisprudence. In the US, both courts decisions refer to fundamental rights established by the country's Constitution, as does the Lahore High Court in Pakistan.9

From the perspective of procedural rights, the Aarhus Convention set forth three basic rights concerning public participation in environmental issues: the right to information, the right to participation and the right of access to justice in relation to environmental issues. ${ }^{60}$ When confronted

Pubblico e Diritti Individuali nella Girisprudenza Ambientale della Corte Europea di Diritti Umani (Editoriale Scientifica, Napoli, 20I3).

57 The ECtHR's case law on the matter is so vast that it even published a factsheet summarizing most of those cases in 20I5. ECtHR, Environment and the European Convention on Human Rights, Factsheet (ECtHR Press Unit, 20I5). In the American system, see for example Inter-American Court of Human Rights, Case of Kawas-Fernández v. Honduras, Merits, Reparations, and Costs, Judgment of 3 Apr. 2009, Series C No. 196 or Case of Claude-Reyes et al. v. Chile, Merits, Reparations, and Costs, Judgment of ig Sept. 2006, Series C No. 151, cited in L. Lixinski, 'Treaty Interpretation by the InterAmerican Court of Human Rights: Expansionism at the Service of the Unity of International Law' 2I (3) The European Journal of International Law (2010), pp. 585-604, at 595-596 [doi: I0.1093/ejil/chq047]. In Africa, at the domestic level, Gbemre v. Shell Petroleum Development Co. Nigeria Ltd., FHC/B/CS/53/05 (Nigeria, 2005), cited in Oslo Principles on Global Climate Obligations, supra n. 3. At the regional level, it is worth noting the African Commission on Human and Peoples' Rights' decision in the Ogoni case: The Social and Economic Rights Action Center and the Center for Economic and Social Rights v. Nigeria, African Commission on Human and Peoples' Rights, Comm. No. 155/96 (200I).

58 The clearest example of that situation might be the Pacific Islands states, some of which, like Kiribati, are already preparing for a very likely need of future displacement of their nationals due to sea rising (http://www.climate.gov.ki/category/action/relocation/). As a response to their vulnerability to climate change, the Climate Vulnerable Forum was created in 2009, gathering 43 developing countries. See http://www.thecvforg/.

59 Zoe and Stella Foster et al. v. Washington Department of Ecology, supra n. 7, citing "other rights retained by the people", at 8-9. In Kelsey Juliana although the Court has, thus far, pronounced itself only in relation to the motions to dismiss presented before it and, therefore, has not yet examined any evidentiary records, it certainly considers the matter in relation to due process rights. Kelsey Juliana v. The United States of America, supra n. II, at 15-17. Ashgar Leghari v. Federation of Pakistan, supra n. Io, at 5-6

60 Convention on Access to Information, Public Participation in Decision-Making and Access to Justice in Environmental Matters, 25 June 1998, Aarhus (Denmark), in force 30 Oct. 200I. The literature on the subject is vast. See, for a general overview, E. Morgera, 'An Update on the Aarhus Convention and its Continued Global Relevance', I4 (2) Review of European, Comparative of International Environmental Law, (2005) I38-I47 [I0.IIII/j.I467-9388.2005.00434.X]. On the evolution of the Aarhus Convention in the EU context, see M. Pallemaerts, The Aarbus Convention at Ten: Interactions and Tensions Between Conventional International Law and EU Environmental Law (Europa Law Publishing, 20II). For an analysis of the impact of the Aarhus Convention on the climate change regime, see S. Duyck, 'Promoting the Principles of 
to a climate change case, courts refer more often to the last two, but we will be analysing this question in more detail in a following section, when dealing with the ius standi dimension of the different lawsuits object of this study.

It is also worth noting that, although a regional convention drafted under the auspices of the United Nations Economic Commission for Europe (UNECE), the relevance of the Aarhus Convention has extended well beyond European borders, both at the judicial and policy level.

From a judicial point of view, different regional courts have progressively started to refer to the Aarhus Convention. In the case Claude Reyes v. Chile, the Inter-American Court of Human Rights declared in its judgement the extension of the right to freedom of thought and expression so as to include the protection of the right to access information held by the State, while citing legal sources that go beyond the Inter-American system, like Article io of the Rio declaration of 1992 or the Aarhus Convention. ${ }^{61}$

In a convergent decision, the Court of Justice of the Economic Commission of West African States (ECOWAS) established, in examining the ius standi of the plaintiff - an NGO - that "[t]here is a large consensus in International Law that when the issue at stake is the violation of rights of entire communities, as in the case of the damage to the environment, the access to justice should be facilitated", ${ }^{2}$ and based its statement on the Aarhus Convention, while recognizing that "[a]lthough the convention is not a binding instrument on African States, its importance, as a persuasive evidence of an international communis opinion juris in allowing NGOs to access the Courts for protection of Human Rights related to the environment, cannot be ignored or underestimated by this court". ${ }^{63}$

At the policy level, former UN Secretary General Koffi Annan and Ban Ki Moon have also referred in laudatory terms to Aarhus, as a cornerstone for both environmental and human rights justice, ${ }^{64}$ and the Economic Commission for Latin America and the Caribbean is currently working on an agreement on procedural rights on environmental matters that might refer explicitly to the Aarhus Convention. ${ }^{65}$

(iii) European Union law

the Aarhus Convention in International Forums: The Case of the UN Climate Change Regime', 22 (4) Review of European, Comparative of International Environmental Law, (2015), I23-138 [doi: 10.IIII/reel.I2125].

6r Supra, in 57 , at $\$ \$ 77-82$.

62 The Registered Trustees of the Socio-Economic Rights \& Accountability Project (SERAP) v. President of the Federal Republic of Nigeria \& ORS, ECOWAS Community Court of Justice, Io Dec 2010, Suit No: ECW/CCJ/APP/o8/o9; Rul. No: ECW/CCJ/APP/07/ro, \$56.

63 Ibid. $\$ 58$

64 "Although regional in scope, the significance of the Aarhus Convention is global. It is by far the most impressive elaboration of principle io of the Rio Declaration", Kofi Annan foreword to The Aarbus Convention: an implementation guide. 2000.

${ }_{65}$ Fifth meeting of the negotiating committee of the regional agreement on access to information, participation and justice in environmental matters in Latin America and the Caribbean, Text compiled by the presiding officers incorporating the language proposals received from the countries on the preamble and articles $I$ to to of the preliminary document on the regional agreement on access to information, participation and justice in environmental matters in Latin America and the Caribbean, Fourth version, I3 September 2016, at 6. 
Finally, the third main source of international law obligations invoked in these proceedings is European Union law, which has provided another solid foundation for many of the climate change cases examined so far, albeit only in Europe. In Urgenda, the court referred primarily to Article 191.2 TFUE, as the legal underpinning of the prevention and the precautionary principle when dealing with environmental issues: ${ }^{66}$

"Union policy on the environment shall aim at a high level of protection taking into account the diversity of situations in the various regions of the Union. It shall be based on the precautionary principle and on the principles that preventive action should be taken, that environmental damage should as a priority be rectified at source and that the polluter should pay." ${ }^{\prime 67}$

The court also mentions Article I9I.I TFUE, which establishes the EU objectives in terms of environmental policy, including climate change.

"Union policy on the environment shall contribute to pursuit of the following objectives:

- preserving, protecting and improving the quality of the environment,

- protecting human health, iscep:

- prudent and rational utilisation of natural resources, isip?

- promoting measures at international level to deal with regional or worldwide environmental problems, and in particular combating climate change." 68 istipep:

Additionally, two EU regulations are considered when analysing the state's responsibility and leeway in relation to climate change policies: the Effort Sharing Decision ${ }^{69}$, which establishes the GHG reduction objectives for all EU countries, and the EU Emissions Trading System. ${ }^{70}$

In fact, EU legislation provides an additional layer of complexity as the member states' margin of discretion in environmental matters is thoroughly conditioned by the acquis communautaire. For instance, in Urgenda, The Netherlands' government argued that it couldn't establish stricter GHG reduction goals because it would interfere with EU legislation. However, the Dutch court held otherwise, affirming that those norms established some minimum criteria, but in no way prevented member states from going further, as far as it didn't increase the emission allowances derived from the ETS:

"[...] In so far as the State hereby argues that in allocating the emission allowances (emission allocation) among the ETS businesses the State should act in accordance with EU legislation and observe the ceiling stated therein, then this is correct. However, the court does not follow the State in this argument in so far as this means that a Member State is not allowed to reduce more than the amount adopted in EU policy.

66 Urgenda v. The Netherlands, supra n. 5, at $\$ \$ 4.60$ and 4.62 .

${ }_{67}$ Consolidated Version of the Treaty on the Functioning of the European Union, supra n. 35 .

68 Ibid.

69 Decision No 406/2009/EC of the European Parliament and of the Council of 23 April 2009 on the effort of Member States to reduce their greenhouse gas emissions to meet the Community's greenhouse gas emission reduction commitments up to 2020 , OJ 2009 L I 40 , p. $136-48$.

70 Directive 2003/87/EC of the European Parliament and of the Council of $\mathrm{I}_{3}$ October 2003 establishing a scheme for greenhouse gas emission allowance trading within the Community and amending Council Directive 96/6r/EC, OJ 2003 L275/32, lately amended by Directive 2009/29/EC of the European Parliament and of the Council of 23 April 2009 amending Directive $2003 / 87 / \mathrm{EC}$ so as to improve and extend the greenhouse gas emission allowance trading scheme of the Community, OJ L I 40, 5.6.2009, p. 63-87. 
Urgenda was right in arguing that regardless of the ceiling Member States have the option to influence (directly or indirectly) the greenhouse gas emissions of national ETS businesses by taking own, national measures. In its argument, Urgenda has named several of such measures taken in other Member States, such as increasing the share of sustainable energy in the national electricity network in Denmark and the introduction of the carbon price floor taks [sic] in the United Kingdom, with which the price of $\mathrm{CO}_{2}$ emission has been increased'. ${ }^{\text {T }}$

Incidentally, it can also be noticed that the European Union incorporated the Aarhus principles into EU law through several directives. We will deal with them more in detail below, when analysing the ius standi dimension of the cases examined in this article.

\section{(c) National law}

All of the abovementioned lawsuits rely also, and heavily, on domestic law. Courts in the US and Pakistan primarily base their decisions on national law, basically on their Constitutions and the duty they establish upon States to protect their citizens' rights (from the right to life and the right to health to he right to air quality or to have access to natural resources). In Europe too, claimants and courts alike refer to their respective national law, for it is in domestic law that we find the third pillar of those innovative lawsuits and court rulings by way of the implementation of the duty of care and the tort law perspective.

Thus, The Hague District Court refers to the duty of care of the State towards its citizens, which derives from both the Dutch Constitution" ${ }^{72}$ and the Civil Code.73 The "négligence illicite" in the Klimaatzaak claim mirrors the same notion, as does the "carence fautive" in the "action préalable" (preliminary request) of Notre Affaire d̀ Tous.

The similarities among different legal systems in terms of what are the elements that constitute the duty of care are striking. For instance, in order to establish the existence of a duty of care and assess whether there's been a violation of that duty, the Court in Urgenda considered the following: first, "the nature and extent of the damage ensuing from climate change"; second, "the knowledge and foreseeability of this damage"; third, "the chance that hazardous climate change will occur"; fourth, "the nature of the acts (or omissions) of the State"; fifth, "the onerousness of taking precautionary measures"; and, finally, "the discretion of the State to execute its public duties".74

${ }^{71}$ Urgenda $v$. The Netherlands, supra n. 5, at $\$ 4.80$. The court's interpretation of the State's marge de manoeuvre in relation to the EU ETS has been the object of some criticism. See M. Peeters, 'Urgenda Foundation and 886 Individuals v. The State of the Netherlands: The Dilemma of More Ambitious Greenhouse Gas Reduction Action by EU Member States' (Case Note), 25 Review of European Community of International Environmental Law (2016), I23-I29, at I27-I28 [doi: IO.III/reel.I2I46]. The possibility of a State adopting stricter GHG emission requirements for ETS sectors was analysed even before the lawsuit was presented, and considered of being of dubious legality, in L. Squintani et al., 'Regulating greenhouse gas emissions from EU ETS installations: what room is left for the member states?', in M. Peeters et al. (eds), Climate Law in EU Member States. Towards National Legislation for Climate Protection, (Edgar Elgar, Cheltenham, 2012 ) 67. Conversely, the analysis provided in D. Wyat et al., Does the EU's proposed Directive On Industrial Emissions (IPPC) preclude member states from imposing emission limits for $\mathrm{CO}_{2}$ under national rules other than those implementing the proposed Directive?, Legal advice, $9^{\text {th }}$ February 2010, proves much more favourable to The Hague's court interpretation of the Directive.

72 Article 2I, The Constitution of the Kingdom of the Netherlands (2002).

73 Book 6, section 162, entitled TOR T ("unlawful acts"), Civil Code of the Netherlands (1992).

74 Urgenda v. The Netherlands, supra n. 5, at $\$ \$ 4.63$ and 4.65 . 
Those requisites could be summarized in the following questions: What kind of damages will occur and how serious are they going to be? How apparent is the danger and can the State pretend it doesn't know? How great is the probability that the danger will manifest itself? What are the measures of responsibility taken by the State? How much would it cost to take the measures needed and how much would it cost not to take any action? And, finally, what is the extent of the State's discretionary power in relation to climate change, i.e. is there a legal justification of the State's action or lack of action? Those same questions appear either directly or indirectly in the rest of the abovementioned cases. In Notre Affaire d̀ Tous, for instance, claimants put it in a similar way:

“[...] trois aspects seront pris en compte. La responsabilité s'illustre à la fois dans la nature et l'étendue des dommages encourus, la connaissance et la prévisibilité de ces dommages pour les autorités de l'État et enfin la probabilité que ces dommages se réalisent."75

Likewise, claimants in Kilmaatzaak consider the "violation de la norme de prudence" (the violation of the required prudence or due diligence), ${ }^{76}$ "le dommage" (damage) and "la causalite" (causality) in order to verify the unlawfulness of the reckless behaviour of the State.77

On the other side of the Atlantic, in the US, the King County Superior Court refers to the interaction of the duty required by law and the public trust doctrine to achieve a similar result. As the Court points out, the State has a legal duty to "adopt rules establishing air quality standards", as defined by the Clean Air Act, but, in addition to that, the State has a duty that comes from the public trust doctrine deriving from the Constitution. ${ }^{7}$ Claimants in Kelsey Juliana also rely heavily on the duty of care and the Court acknowledged the relevance of the argument when combining the duty to act of the State and its public trust duties in its order denying the motions to dismiss previously filed by the State and the oil industry intervenors.79

In Pakistan, the Lahore High Court Green Bench has also referred to the public trust doctrine as one of the legal constructs underlying the State's obligation to protect the fundamental rights of citizens ${ }^{80}$ thus reaffirming the widespread use of that notion in climate change domestic litigation around the world.

As a matter of fact, essential to the matter being discussed here is the notion of discretionary power. In that sense, The Hague District Court's judgement is enlightening. After analysing all the different elements mentioned above, the Court concluded that the State has a duty of care and that it is actually in breach of its duty. If the State were to respect that duty it would set a stricter climate change policy with more ambitious GHG emissions' reduction targets, of at least $25 \%$ in 2020 as compared to

\footnotetext{
75 "(...) three aspects should be considered. Responsibility derives at the same time from the nature and the extent of the expected damages, the knowledge and predictability by the State authorities of those damages and, finally, the probability that those damages will actually happen" (Translation by the author). Notre Affaire à Tous, Résumé de la déclaration préalable. I8 Dec. 20I5. Neither published nor available at the world wide web.

${ }^{6}$ Claimants state that due diligence goes beyond respecting the law, as it must complete what the law says.

77 Klimaatzaak v. Belgium, supra n. 9, at 26-32.

78 Zoe and Stella Foster et al. v. Washington Department of Ecology, supra n. 7, at 6-8.

79 "When combined with the EPA's duty to protect the public health from airborne pollutants and the government's public trust duties deeply ingrained in this country's history, the allegations in the complaint state, for purposes of a motion to dismiss, a substantive due process claim”. Kelsey Juliana v. The United States of America, supra n. II, at 23.

8० Ashgar Lebari, supra n. I0, at 6.
} 
the 1990 levels. This derives from the established science that tells us about the dangers to come (science that the State itself acknowledges through the documents and reports produced by national authorities), as well as from the obligations deriving from international law, human rights law and national law, and from the fact that acting now it's going to have a much lesser cost than delaying action or not acting at all. ${ }^{8 .}$

Hence, the Court concludes, the State does not have a discretionary power not to comply with this level of GHG reductions. What it does have is a discretionary power to choose among the different policies that would allow the authorities to achieve that goal. ${ }^{82}$

The scope of the State's discretionary power is also dealt with in both Foster and Kelsey Juliana. In the former, for instance, the Court found that the State has an obligation to protect trust resources under its administrative jurisdiction and, although it initially abstained from enjoining the Washington Department of Ecology to adopt measures and legislation in order to fulfil that obligation $^{8_{3}}$-because the Department had already started the process of rulemaking following a directive issued by the Governor of the State-, it ordered the Department to proceed with the rulemaking procedure, thus granting the motion for relief presented by the petitioners, after it was ascertained that the department of Ecology most probably wouldn't complete the rulemaking procedure by the end of 2016 in the absence of a court order. ${ }^{84}$

The words of the judge during the hearing of 29 April 2016, explaining his decision to oblige the State to take action, are crystal clear and make a strong case for climate change domestic litigation:

"The reason I'm doing this is because this is an urgent situation. This is not a situation that these children can wait on. Polar bears can't wait, the people of Bangladesh can't wait. I don't have jurisdiction over their needs in this matter, but I do have jurisdiction in this court, and for that reason I'm taking this action." ${ }^{85}$

The Court in Kelsey Juliana joins this line of thought and also states a clear view on the limits between the exercise of its jurisdictional duty and the discretionary power of the State when addressing what it calls "the political question":

"[...] the intractability of the debates before Congress and state legislatures and the alleged valuing of short term economic interest despite the cost to human life, necessitates a need for the courts to evaluate the constitutional parameters of the action or inaction taken by the government. This is especially true when such harms have an alleged disparate impact on a discrete class of society. ${ }^{86}$

[...] While courts cannot intervene to assert "better" policy (...), they can address constitutional violations by government agencies and provide equitable relief. (...) The court need not dictate any

8I Urgenda v. The Netherlands, supra n. 5, at $\$ 4.83$ to 4.86 .

82 Ibid., at $\$ \$ 4.94$ to 4.102 . Of special interest are $\$ 4.53$ ("the State's discretionary power is relevant in assessing the government's actions. From case law about government liability it follows that the court has to assess fully whether or not the State has exercised or exercises sufficient care, but that this does not alter the fact that the State has the discretion to determine how it fulfils its duty of care. However, this discretionary power vested in the State is not unlimited: the State's care may not be below standard."), and \$4.IOI ("If the claim is allowed, the State will retain full freedom, which is preeminently vested in it, to determine how to comply with the order concerned.").

${ }_{83}$ Zoe and Stella Foster et al. v. Washington Department of Ecology, supra n. 7, at 6-8.

${ }_{84}$ Zoe and Stella Foster et al. v. Washington Department of Ecology, supra n. 8, at 2-3.

85 Zoe and Stella Foster et al. v. Washington Department of Ecology, No. 14-2-25295-I SEA, Hearing, 29 April 2016.

86 Kelsey Juliana et al. v. The United States of America et al., supra n. II, at 8. 
regulations, only direct the EPA to adopt standards that prevent the alleged constitutional harm to the youth and future generation plaintiffs, should plaintiffs prevail in demonstrating such is possible." ${ }^{77}$

\section{(3) Ius Standi}

\section{(a) Access to courts}

Another relevant question raised by those lawsuits concerns who has the legal capacity to bring the State to justice in order to review its climate change policy.

We can identify here a difference between, on one side, the cases in the US and Pakistan and, on the other, those in continental Europe. While in the former it is, primarily, individuals who decide to bring an action to court, in the latter it is non-profit organizations that take the lead. ${ }^{88}$

Usually, in order to go to the courts, it is required to have a direct interest on the matter, which is clear in the case of citizens affected or under the menace of climate change. However, when dealing with non-profit organizations there's a different regime that has evolved slowly towards a more coherent ensemble among European countries since the adoption of the Aarhus convention.

In the Netherlands, for example, since 1994 the Civil Code allows for collective actions brought about by associations or foundations. ${ }^{89}$ In France, there's a similar disposition deriving from a 1995 law..$^{\circ}$ In Belgium, on the contrary, the Supreme Court held for 30 years that non-profit organizations were not allowed to present a case concerning a general interest or an interest based exclusively on its by-laws. This changed in 2013, after the Court switched its jurisprudence as a consequence of the obligations imposed to Belgium by the Aarhus convention..$^{91}$

As previously mentioned, Aarhus basically recognises three rights to natural and legal persons: (i) the right to be informed concerning environmental issues (and the duty of the State to inform), (ii) the right to participate in the decisions relating to environmental issues and (iii) the right of access to justice concerning environmental matters. The first two were translated into EU Directives in $2003,{ }^{92}$ but the Directive concerning the right of access to justice, although drafted, hasn't been approved since. ${ }^{93}$

87 Ibid, at I3-I4.

88 This is also the case in the climate lawsuits recently filed in Sweden and Norway, supra n. I3.

89 Book 3, Article 305a, Civil Code of the Netherlands, supra n. 68.

90 Loi $n^{\circ} 95-$ IOI du 2 février 1995 relative au renforcement de la protection de l'environnement. More recently, Article L I42-I du Code de l'Environnement.

9r PDS, "Eikendael-doctrine niet langer houdbaar", TMR 2013, 357-358, cited in Klimaatzaak v. Belgium, supra n. 9, at 5.

92 Directive $2003 / 4 /$ EC of the European Parliament and of the Council of 28 January 2003 on public access to environmental information and repealing Council Directive 90/313/EEC, [2003] OJ L 4I, and Directive 2003/35/EC of the European Parliament and of the Council of 26 May 2003 providing for public participation in respect of the drawing up of certain plans and programmes relating to the environment and amending with regard to public participation and access to justice Council Directives 85/337/EEC and 96/6I/EC, [2003] OJ L I56.

93 There was a laconic statement on the matter by the European Commission, affirming that it was envisaged for the first quarter of 2003. A study was conducted in 20I3, with the participation of experts from all around Europe, which concluded on the necessity to adopt a EU Directive on access to justice in environmental matters along very similar lines to the 2003 proposal: J. Darpö, Effective Justice? Synthesis report of the study on the Implementation of Articles 9.3 and 9.4 of the Aarbus Convention in the Member States of the European Union (2013). 
Consequently, EU countries have developed different regimes, with some of them, like Spain, adopting legislation that broadly translates what was intended in the draft Directive on access to justice, ${ }^{94}$ which could, probably, allow for a similar lawsuit to be filed in their domestic courts.

\section{(b) What norms can the public prevail itself of?}

The other relevant question in this matter concerns the right of the claimants, either natural or legal persons, to rely on the abovementioned principles and legal norms in order to request a remedy from the courts.

The Urgenda judgement is, again, noteworthy in this subject. After having analysed the obligations deriving from international law and human rights law, the court concludes that Urgenda can't rely on those legal instruments to affirm that there's a legal obligation of the State towards that organization:

"The foregoing leads the court to conclude that a legal obligation of the State towards Urgenda cannot be derived from Article 2I of the Dutch Constitution, the "no harm" principle, the UN Climate Change Convention, with associated protocols, and Article 19I TFEU with the ETS Directive and Effort Sharing Decision based on TFEU."95

The Court argues that, regarding international law, the conventions and principles already mentioned create obligations only among states. ${ }^{96}$ And as regards human rights, the Court recalls that it has been consistently established by the ECtHR that a legal person's physical integrity cannot be violated nor can a legal person's privacy be interfered with. ${ }^{97}$

Nonetheless, the court analyses those norms and takes them into consideration as an interpretative tool that helps defining the obligations of the State towards Urgenda that derive from its national legislation. Therefore, and crucially, international norms might be very relevant but, not being selfexecuting, they would instead serve as an essential interpretative basis to help substantiate nationally determined obligations:

"Although Urgenda cannot directly derive rights from these rules and Articles 2 and 8 ECHR, these regulations still hold meaning, namely in the question discussed below whether the State has failed to meet its duty of care towards Urgenda. First of all, it can be derived from these rules what degree of discretionary power the State is entitled to in how it exercises the tasks and authorities given to it. Secondly, the objectives laid down in these regulations are relevant in determing [sic] the minimum degree of care the State is expected to observe. In order to determine the scope of the State's duty of care and the discretionary power it is entitled to, the court will therefore also consider the objectives of international and European climate policy as well as the principles on which the policies are based."98

94 Law 27/2006, I8 July 2006, concerning the regulation of the rights of access to information, of public participation and of access to justice on environmental matters (incorporating Directives 2003/4/CE and 2003/35/CE). (BOE no. 171, 19 July 2006).

95 Urgenda v. The Netherlands, supra n. 5, at $\$ 4.52$.

96 Ibid., at $\$ 4.42$.

97 Ibid., at $\$ 4.45$, citing Identoba et al. v. Georgia, ECtHR, I2 May 2015, appl. no. 73235/12, [2015].

$98 \quad$ Ibid., at $\$ 4.52$. 
(C) FINAL REMARKS

(I) The recent development of academic initiatives on legal principles relating to climate change

\section{(a) A remarkable coincidence in time}

We have seen how in the last four years several proceedings have been initiated in courts all around the world. And there are probably more coming. The outcome of the appeal against Urgenda's first instance decision, as well as the outcome of the lawsuits already started in Belgium and the US will clearly have a strong influence on the development of further lawsuits in other countries.

Those cases span from 2013 until now, and almost at the same time, several initiatives from international law scholars and practitioners have tried to provide a solid basis of international legal principles concerning climate change.

Among these, we can cite the 2013 Universal Covenant affirming a buman right to commons -and rights- based governance of Earth's natural wealth and resources, prepared for the Commons Law Project, 99 or the 2014 International Law Association Declaration of Legal Principles Relating to Climate Change. ${ }^{100}$ Also since 20I4, the International Bar Association Working Group on Climate Change Justice has been working to draft a Model Statute on Legal Remedies for Climate Change, which hasn't been published yet. ${ }^{\mathrm{ror}}$ Most recently, at the end of March 2015 several leading jurists presented the Oslo Principles on Global Climate Change Obligations. ${ }^{\mathrm{IO2}}$

More than just a coincidence, this might be a symptom of the impasse reached at the time concerning the definition by the international community of clear, sufficiently ambitious and legally binding goals concerning "the most serious challenge to humankind in living memory". ${ }^{\circ 03}$

Despite some promising recent signs at the international level, such as the unprecedented speed of ratification and entry into force of the Paris Agreement ${ }^{\mathrm{t}+4}$ or the opportune adoption of the Kigali Amendment to the Montreal Protocol in order to reduce the emissions of HFCs, ${ }^{\text {Ios }}$ in the light of the manifest and unsettling gap between what is considered a safe path of GHG emissions' reduction by

99 B. H. Weston \& D. Bollier et al., Universal Covenant affirming a buman right to commons - and rights-based governance of Earth's natural wealth and resources (2013).

roo Committee on Legal Principles Relating to Climate Change, Declaration of Legal Principles Relating to Climate Change (International Law Association, 20I4). The official draft version with commentaries also provides very interesting insights.

ror This is the result of a recommendation made by the Climate Change Justice and Human Rights Task Force in the 2014 report Achieving Justice and Human Rights in an Era of Climate Disruption, supra n. I8, at I27.

${ }^{102}$ Among the experts, there are judges, advocates, land scholars. A full list of the members can be found at http://globaljustice.macmillan.yale.edu/news/oslo-principles-global-climate-change-obligations. Expert Group on Global Climate Obligations, supra n. 3.

${ }^{103}$ Expert Group on Global Climate Obligations, supra n. 3, at 23.

${ }_{104}$ As of 21 October 2016, already 19I countries had signed the Agreement, which reached the required threshold of ratifications (both in terms of number of countries and volume of emissions) on 5 October 2016 and will be entering into force on 4 November 2016. As of 2r October 2016, 82 States were officially parties of the Agreement (according to the UN Treaty Collection website). UNFCCC, Decision I/CP.2I, Adoption of the Paris Agreement (UN Doc. FCCC/CP/2015/Io/Add.I, 29 January 2016).

ros UNEP, Further Amendment of the Montreal Protocol. Submitted by the Contact group on HFCs, Twenty-Eighth Meeting of the Parties to the Montreal Protocol on Substances that Deplete the Ozone Layer, Kigali, (UNEP/OzL.Pro.28/CRP/ro, I4 October 2016). 
the majority of scientists, and the GHG emissions' reduction likely to be obtained from the addition of the Intended Nationally Determined Contributions (INDC) of states parties to the UNFCCC, ${ }^{\text {106 }}$ it shouldn't be surprising to see both "judicial decisions and the teachings of the most highly qualified publicists of the various nations" ${ }^{\text {107 }}$ analyse and further develop legal mechanisms to ensure the adequate safeguard of those essential international goods.

\section{(b) Many similarities, some differences}

The intellectual and legal reasoning behind those different academic initiatives is often very similar to the one displayed in the different lawsuits we have analysed in this paper. There is not only a coincidence in timing, but in the content as well. We could even see them as reciprocally influencing each other.

The relevance of both the prevention and the precautionary principle is patent in the ILA Legal Principles ${ }^{108}$ as it is a certain dimension of the duty of care. ${ }^{109}$ The authors of the Oslo Principles, on the other hand, inspire themselves in that text and go further, establishing the precautionary principle as the "cornerstone" of all the subsequent obligations they propose ${ }^{\mathrm{IIO}}$ through the intervention of the principles of tort law, much in a similar manner as we have seen in the different cases analysed above.

The composite notion of the duty of care, identified by the Court in Urgenda, echoes the words of the authors of the Oslo Principles when they examine the notion of tort:

"The strongest legal basis for our principles can probably be gleaned from what arguably is a common core of tort law referred to in the U.S. as the Learned Hand formula. It is a fundamental and widely accepted rule of thumb that an act or omission will be unlawful if it subjects the life, well-being or property of others to a risk of damage, if the risk is considerable, if the potential damage is colossal, and if the risk can be avoided without undue detriment to the party/parties causing that risk. Obligations to mitigate climate change meet all these requirements." ${ }^{\text {II }}$

The essential role of science is another of the common traits among the judicial decisions examined in this article and the Oslo Principles, although they may not use them to reach the same conclusions. Probably the most relevant difference among them concerns the scope of the discretionary power of the State and the concrete application of the precautionary principle. As we have seen above, the court in Urgenda decided that it was enough for the State to respect the minimum level of GHG reduction

106 "The INDCs collectively [...] imply a median warming of 2.6-3.I degrees Celsius by 2100. [...] Substantial enhancement or over-delivery on current INDCs by additional national, sub-national and non-state actions is required to maintain a reasonable chance of meeting the target of keeping warming well below 2 degrees Celsius." J. Rogelj et al., 'Paris Agreement climate proposals need a boost to keep warming well below $2{ }^{\circ} \mathrm{C}$ ', 534 Nature (2016), 63I-639 [doi:I0.1038/natureI8307]. The synthesis report to be analysed at COP 22 in Marrakech points to similar results: Aggregate effect of the intended nationally determined contributions: an update. Synthesis report by the secretariat. Conference of the Parties Twenty-second session Marrakech, 7-I8 November 20I6, Item X of the provisional agenda. FCCC/CP/2016/2.

107 United Nations, Statute of the International Court of Justice, I8 April 1946.

${ }_{108}$ Committee on Legal Principles Relating to Climate Change, supra n. Ioo, principles 7.A and 7.B.

rog Commentary 7 on Article 7 of the official draft version with commentaries, supra n. Ioo.

Io Expert Group on Global Climate Obligations, supra n. 3, principle I, at 4. For a thorough analysis of the precautionary principle, see pp. 47-6I.

III Ibid., at 38-47.

II2 Ibid., at 38 . 
identified by the IPCC as likely to keep the increase in the world average temperature below $2^{\circ} \mathrm{C}$. However, considering the scientific evidence in the light of the precautionary principle, the authors of the Oslo Principles affirm that the State is obliged to reduce its emissions to the maximum level required to make sure that the $2^{\circ} \mathrm{C}$ goal will be achieved.

Thus, concerning the 2020 reduction targets, The Hague District Court considers it sufficient for the State to reach a reduction of $25 \%$ :

Although it has been established that the State in the past committed to a $30 \%$ reduction target and it has not been established that this higher reduction target is not feasible, the court sees insufficient grounds to compel the State to adopt a higher level than the minimum level of $25 \%$. According to the scientific standard, a reduction target of this magnitude is the absolute minimum and sufficiently effective, for the Netherlands, to avert the danger of hazardous climate change, but the obligation to adhere to a higher percentage clashes with the discretionary power vested in the State, also with due regard for the limitation discussed here. ${ }^{\mathrm{II}}$

Conversely, the authors of the Oslo Principles take the opposite view and maintain that states should aim at the highest reduction suggested by scientific evidence.

"We quite strongly believe that this [precautionary] principle requires reliance on the most demanding reduction scenario submitted by IPCC or, if more demanding, by a substantial number of other eminent experts. According to IPCC:

'Scenarios that are likely to maintain warming at below 2 C are characterized by a $40 \%$ to $70 \%$ reduction in GHG emissions by 2050, relative to 2010 levels, and near zero in 2100.'

In our view, a mere likelihood of "66-roo\%" is an insufficiently sound and safe basis to determine the reductions of GHGs legally required. If the just-mentioned scenario were to serve as the basis for calculations of the reductions legally required, the highest percentage (70) should be adopted."114

(2) The great but fragile potential of national climate change litigation

In the face of the unprecedented threats posed by climate change and the lack of sufficiently ambitious agreements at the international level, it is inspiring as well as comforting to see national courts step in to protect global interests through the use of international law. As a dynamic system, law (and international law as well) must adapt in order to be able to respond to new realities. One can but hope that those lawsuits will foster the definition of standards of protection that will safely prevent us from the already looming catastrophe of climate change.

However, we must not forget the uncertainty surrounding those proceedings and we should be very careful before praising them as the decisive step to ensure legal protection against climate change. As the authors of the Oslo Principles significantly point out, not all judges and courts will be willing to admit or review such cases, and even less of them will be willing to decide in favour of the claimants. ${ }^{\text {II }}$ Moreover, even relevant steps taken by states in the good direction to mitigate climate change might be blocked by courts when balancing them against other legal considerations. ${ }^{\mathrm{II}}{ }^{6}$

II3 Urgenda v. The Netherlands, supra n. 5, at $\$ 4.86$.

I4 Expert Group on Global Climate Obligations, supra n. 3, at 56-57.

IIs Ibid., at 45-46.

II6 See for example the United States Supreme Court's decision, early this year, to temporarily block the EPA regulation concerning power plants emissions across the US. State of West Virginia, et al. v. EPA, U.S. Supreme Court, No. 15 A773. 
In that sense the potential heterogeneity of judicial decisions, even more among different national jurisdictions, should be reason enough to keep on pushing for ambitious and effective international norms concerning climate change. In the meantime, the increasingly concurring and mutually reinforcing arguments of courts and scholars around the globe can provide an invaluable legal kickstand on which to build the indispensable protection for our, so far, only home in the universe. ${ }^{\text {II }}$

We can reasonably expect that the recent and almost unanimous adoption and signature as well as the unexpectedly swift entry into force of the Paris Agreement will reinforce those claims. Indeed, countries in Paris agreed to hold the increase in the global average temperature to "well below $2^{\circ} \mathrm{C}$ above pre-industrial levels and to pursue efforts to limit the temperature increase to $1.5^{\circ} \mathrm{C}$, ${ }^{118}$ which is the most ambitious goal ever set forth in a global international agreement. Additionally, Parties also "aim to reach global peaking of greenhouse gas emissions as soon as possible" ${ }^{\text {I9 }}$ and each party shall determine more ambitious national contributions, reflecting "its highest possible ambition" every five years. ${ }^{120}$ In fact, to a certain extent, it could be argued that the shift from a system where reduction targets for every State party are defined in an international agreement towards a system of nationally determined reduction targets (a system marked by flexibility and differentiation), ${ }^{\mathrm{In}}$ emphasizes each State's domestic responsibility towards its citizens and their duty to define ambitious enough climate policies to achieve those goals, hence reinvigorating the role of domestic courts in assessing those policies.

Ir7 In a relevant exercise of international comparative jurisprudence, the court in Kelsey Juliana even refers to the Urgenda judgment to underline the 'redressability of the injury' through a reduction of the GHG emissions by the US. Kelsey Juliana v. The United States of America, supra n. II, at II.

II8 Supra n. 104, Article 2.I(a).

III Ibid. Article 4.I.

r2o Ibid. Article 4.3.

${ }^{\mathrm{I2}}$ J. E. Viñuales, 'The Paris climate agreement: an initial examination', 6 C-EENRG Working Papers (2015), I-25, at I7I8 [doi: I0.2139/ssrn.2704670]. 